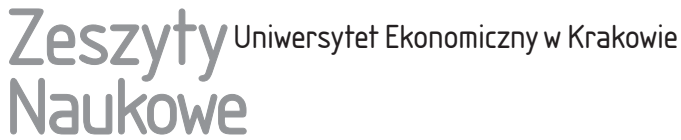

\section{Transforming Ukraine from Grainbasket to Brainbasket: The Role of the Diaspora}

\begin{abstract}
The article identifies the role of diaspora in the development of Ukraine's tech sector. It presents a review of the literature on diaspora in order to deepen understanding of the term and how diaspora differs from migration. It looks at other countries in which diaspora communities played a key role in economic development and applies these findings to legitimise, the analysis of Ukraine.

To learn more about the undertakings of those in the diaspora as well as their motives as they apply to Ukraine's tech sector, empirical studies were conducted in the form of in-depth interviews. The results show that the diaspora contributes in numerous dimensions of Ukraine's economic development, including the tech sector. The main motive of activities distinguishing diaspora from non-Ukrainian entrepreneurs is the sense of responsibility those who have gone forth feel for Ukraine's well-being.
\end{abstract}

Keywords: diaspora, migration, Ukraine, technology, economic development. JEL Classification: O14.

\section{Introduction}

Key figures in Ukraine's business environment argue that emigre entrepreneurs, accomplished abroad, may play a critical role in exploiting Ukraine's potential as a solid engineering and education base. Specifically, it is believed that expertise 
and skills acquired in societies with advanced tech industries can help Ukraine build out and leverage its own tech sector. Given that embracing a high-tech path is the only option for further development of Ukraine, a strong commitment from the Ukraine's diaspora community is of the utmost importance.

Considering the projections of domestic and international experts (Foresight of Ukrainian Economy 2017), this article argues that Ukraine is already on the inevitable transformation path from a resource-based economy to a tech-based one. It also discusses the auxiliary role the diaspora will play in Ukraine's conversion to a high-tech country, or brainbasket. However, it leaves aside the question of what it would take for the diaspora, solely, to revolutionise Ukraine's tech sector.

With this in mind, the initial aim of the study is to examine the notion of "diaspora" and to describe the features which make them a valuable component of homeland prosperity. Secondly, the article evaluates the current scope of diasporic activity targeted at boosting Ukraine's technology potential, which will be responsible for the country's further growth. Accomplishing these two aims will enable me to achieve the ultimate goal of the research - to draw the world's attention to the present state of affairs of these issues, which in turn could stimulate even greater commitment on the part of the dispora.

The paper is divided into five parts. For the purpose of displaying the core nature of diaspora, as well as accentuating the differences between the terms "diaspora" and "migration", the first part thoroughly examines the definitions of the term "diaspora". The second part puts forward arguments in support of the claim that diasporans possess unique assets over non-diaspora business partners when it comes to deal making. The third part reviews case studies of countries that underwent economic development in which the diaspora played a key role. The fourth part explains my motivation in producing this research.

Finally, I report on the results of an in-depth interview with a key informant, who belongs to the diaspora community and holds an executive role in the country's tech sector. The information he provides clarifies the motives of undertakings which distinguish diaspora from non-Ukrainian entrepreneurs. The results of the interview are followed up by analysis and conclusions.

The study possesses geographic limitations. Particularly, the findings of the in-depth interview are limited to a single country - Canada. But diaspora means dispersed around the world. So the research issue is looked at through the prism of one state hosting the transnational population, not the diaspora community as a whole.

The research is intended to deepen the knowledge of the subject for Ukraine as a nation-state, foreign investors, policymakers, and academics. Most importantly, the paper may draw the attention of diasporic entrepreneurs considering 
establishing activity in Ukraine, and facilitate possible policies aimed at boosting diasporan engagement.

\section{What Is Diaspora and How Does It Differ from Migration?}

"Diaspora" is a broad term. The word diaspeirō was first used by the Greeks to describe the act of scattering seeds (Herodotus, as cited in Constant \& Zimmermann 2016, p. 1111). Just like the seedling, the term designates diaspora's tendency to naturalise a new territory - through laying new roots, dispersal and cultural expansion.

Of course, the term has not been limited to Greek. Millennia after its initial use, K. Tötölyan (1991) maintained that "diaspora once described Jewish, Greek, and Armenian dispersion but now shares meanings with a larger semantic domain that includes words like immigrant, expatriate, refugee, guest - worker, exile community, overseas community, ethnic community" (Tötölyan 1991, p. 4). The author defines the term "diaspora" as "the exemplary communities of the transnational moment" (Tötölyan 1991, p. 5). He also cites the Gulf War in order to confirm the legitimacy of a nation-state. Even if a country's strictly defined borders are in a state of erosion to the extent that it loses its sovereignty, nationhood struggles to be preserved. The Tibetans, Kurds and Palestinians serve as an example. Their homeland is retained in their consciousness as the cradle of culture and identity, though it no longer physically exists.

Regardless of whether diaspora has its own state or not, W. Safran (1991, p. 83) grants it inherent features. These are a history of spreading out, nostalgia for homeland and providing support to it, alienation in the host country, and a desire to eventually return - all resulting in a strong sense of collective identity. The notion of returning home plays the role of ethnic bond-strengthening myth, when religion no longer can. Diaspora members do not go back for good to a homeland. This is due either to losing political, ideological, and social self-identification with a state, or to the inconvenience and disruption of one's lifestyle.

While numerous similarities can be found in the diverse works describing diaspora, the term takes on a number of different formulations. A. F. Constant and F. Zimmermann (2016) investigated its etymology, determining that "diaspora is a well-defined group of migrants or those with migrant background with a joined cultural identity and ongoing identification (active or dormant) with the country or culture of origin as they perceive it" (Constant \& Zimmermann 2016, p. 1113).

This interpretation as well as other diaspora discourses typically revolve around experiences of relocation, of settling down in a new place. Although diaspora is generally associated with immigrants, a variety of collective experiences, 
characterising both terms - "diaspora" and "immigration" - reveal considerable differences between their nature. Both for immigrants and diaspora, mobility is essential. Whereas migration anticipates the mobility of one person, a family, or a community, diaspora never relates to an individual. Rather, it is about "the stock of immigrants in several countries for many years" (Constant \& Zimmermann 2016, p. 1113).

Furthermore, in contrast to migration, which connects both flows and stocks, diaspora encompasses stock exclusively, and can even represent the country's citizens of a foreign descent, whose ethnic identity towards their homeland is latent, but can become active once a trigger event occurs.

Another difference between migration and diaspora can be found in J. Clifford's (1994) writing, "in assimilationist national ideologies such as those of the United States, immigrants may experience loss and nostalgia, but only en route to a whole new home in a new place" (Clifford 1994, p. 307). This illuminates the tendency of individuals to integrate with a new national community quite smoothly. Diaspora, on the other hand, is perceived as groups dispersed in different countries, which cultivate strong ties with a homeland but cannot assimilate that easily.

People within those groups are unified by a sense of identity, which is made up of collective experiences of displacement, of abandoning their ancestral homeland either voluntarily or coercively. Hence, their common background and historical evidence cannot be eliminated, prevnting them from fully assimilating.

In addition to a feeling of affiliation, both political and socioeconomic factors further distinguish diaspora from migration. A. F. Constant and K. F. Zimmermann (2016, p. 1114) contend that the words "migration" and "immigrants" are typically related to a host country, prompting discussion of economic outcomes. Migration also leads to policies regarding a number of people arriving in a host country as well as the specifics of skills they can offer on its labour market. In Europe, for example, public discourse is mainly focused on domestic policies, projecting naturalisation, integration and multicultural society. In the US debate, the main emphasis is on illegal immigration. Diaspora, in turn, is never linked to undocumented immigrants. In terms of policies, diaspora is far more related to a home country and its economic development than migration is.

Furthermore, a diaspora can support its home country through lobbying its economic and political interests. Diasporic lobbying power can even lead to government or regime change in their home countries. It can also mediate and help to resolve armed conflict in which the host country is involved. Diasporas thus become informal actors that can influence the host country's foreign policy. 


\section{What Makes Diasporans Good Business Partners?}

Do diasporans make good business partners? Do their unique abilities help boost the economy?

R. Kloostermann, J. van der Leun and J. Rath (1999) use the term "mixed embeddedness", which may endow diasporans with a unique ability to recognise business opportunity thanks to their being embedded in the social, economic, and institutional contexts of two or more different countries. In other words, diversified knowledge, accumulated through first-hand exposure and experiences in both countries, increases entrepreneurial alertness. Provided they possess industry information about how markets function, what customers expect, the legal system and general characteristics of two countries, diasporans tend to recognise unique business opportunities where locals fail to do so.

Being connected to two or more countries, diasporans also have access to a larger pool of customers to select from. Knowing different markets, the possible problems that customers may face and ways to cater to their needs, they can choose their customer segment from their homeland or host country, or both. According to A. Harima and S. Vemuri (2015, p. 35), this unique knowledge enables diasporans to efficiently serve customers of the country of origin (COO) or country of residence (COR) on customer relationships, value proposition and channels. A. Harima and S. Vemuri assume diasporans are able to change an existing business model in the COR targeting customers in the COR, or into a new business model in the COR targeting customers in the COO, or the other way around (Harima \& Vemuri 2015).

A great deal of attention has been also devoted to the concept of the diaspora network. Defined as a network with co-ethnics worldwide, it has been studied by J. B. Meyer and J. P. Wattiaux (2006), Y. Kuznetsov (Diaspora Networks... 2006), D. G. Dutia (2012), M. Elo (2014). The main business privileges diaspora networks bring include: access to labour (Damm 2009), customers (Bowles \& Gintis 2004, Anthias 2007), the ability to acquire external resources and sustain motivation (Harima 2014). Having an extensive network among both a local population and co-diasporans scattered all over the world, diasporans can choose key partners or key resources from the locations where co-diasporans live.

Apart from the ability to draw human resources or counterparties from different resource bases, another important factor is the enhanced cooperation between ethnically linked businesses and close social ties. A state of similarity may compel diasporans to interact more sentimentally and to trust one another. P. F. Lazarsfeld and R. K. Merton (1954), J. Thibaut and H. Kelly (1959), G. Homans (1961), and S. Bowles and H. Gintis (2004, p. 3) point out that networks originate partly because of people's choice to associate with those similar to themselves in some salient respect. The characteristics on which this choice operates include race and 
ethnic identification and religion. Desire to stick to people similar to oneself at the same time tends to cause people to avoid interactions with those of a completely different culture.

S. Bowles and H. Gintis (2004) affirm that networks based on parochialism ${ }^{1}$ can deal with economic problems that are resistant to market- or state-based solutions. For example, in the case of business cooperation, valuing the payoffs other parties gain within the diasporic network, diasporans display higher altruism toward ethnically similar individuals than towards "outsiders". The greater altruism also results in another asset - the solving capacity of networks, namely contractual enforcement mechanisms. Simply put, effective punishing of those who fail to keep promises is "facilitated by close social ties, frequent and variegated interactions, and the availability of low cost information concerning one's trading partner" (Bowles \& Gintis 2004, p. 2).

While reduced information costs contribute to contractual enforcement, transaction costs between members of a diaspora network are generally lower than among "outsiders". Saving intermediary fees such as those charged by consultants, analysts, translators and lawyers that attend the entrance to an unknown market is possible thanks to the social ties and trust developed within one's community. The arguments put forward in this section can make diasporans not only good business partners but equally rational investors and solid counterparties.

\section{Building a Country from Abroad}

Seeking to improve one's income is the main initial objective triggering migration. Yet it is not the ultimate goal. According to M. Nikolova, M. Roman and K. F. Zimmermann (2016, p. 5), "looking at migration's effects only in terms of objective or subjective well-being is important, yet furnishes an incomplete perspective about the broader social consequences of emigration". They showed that emigration directly benefits the overall state of the society left in the home country.

A study done on Romania and Bulgaria found that there is a positive interdependence between having relatives abroad and pro-social behaviour of those who have stayed behind, including charity and helping strangers, and is driven by positive experiences of friends and family living in countries with advanced civil societies.

Examining the social impact of diaspora is of great importance as long as society shapes the state, which in turn projects the policies behind the coun-

${ }^{1}$ Exlusionary practices, in which decentralised groups such as close knit residential neighbourhoods and ethnically linked groups engage (Bowles \& Gintis 2004). 
try's economic development. Yet there are various ways for diaspora to enhance economic development and growth directly, not only through society. As reported by D. R. Agunias and K. Newland (2012, p. 113-126), remittances are a crucial means by which diasporans contribute to the development of their home countries. Constituting an additional source of income, remittances improve the living standard while improving access to health care and education for those still in the country. Healthy and educated individuals now have the opportunity to become a skilled labour force, entrepreneurs and innovators. These positive developments help reduce poverty and spur investment growth.

While remittances undoubtedly constitute meaningful support for individuals and families, they mainly cover expenditures for daily consumption. Thus, they may not be relied on as the sole drivers of fundamental and sustainable economic growth (Agunias \& Newland 2012). Given the substantial volume of financial flows and other forms of aid coming from diasporic communities, it is increasingly being scrutinised how to mobilise this potential in order to boost capital injection, promote trade and enhance commercial activity in the countries of origin.

Q. Dhanani and M. Lee (2013) indicate that the Caribbean diasporas mostly invest in startup companies that prioritise the Caribbean region. "Access to finance is a critical piece of the stronger innovation ecosystem required for small and medium enterprises (SMEs) and high-potential growth-oriented enterprises (HGEs) to prosper" (Dhanami \& Lee 2013, p. 6).

Given the integral role of SMEs in a country's economic development, the direction of the Caribbean investment is noble. However, individuals in the diaspora seem by default to have privileges as foreign investors. For instance, from 1985 to 2000, diasporic contributions accounted for nearly 70\% of China's foreign direct investment (Diaspora Networks... 2006, p. 13). The authors of that study find that the diaspora had the advantage over non-Chinese entrepreneurs by knowing the local language, business practices, and regulations. This kind of expertise, as well as extensive networks and experience in doing business, helped them to overcome the market barriers that frustrate foreign investors the most.

While Hong Kong Chinese directly invested in China's manufacturing, the Indian and Israeli diaspora contributed to the prominent development of tech sectors in their countries of origin. Even though it is estimated that overseas Indians account only for 3\% of foreign direct investment in India (Diaspora Networks... 2006, p. 13), the success of the country's software industry has been driven mainly by the activity of expatriates.

However, the lack of investment is not justified by the reluctance of Indians to supply it. In turn, it is implied by the specifics of software services. If destined for export, they are highly profitable and provide good cash flow. Hence, most ventures do not need to be funded with external capital. In turn, the Indian dias- 
pora "provides valuable links with foreign markets, helping Indian firms to absorb technical and managerial practices and establish contacts with foreign markets" (Diaspora Networks... 2006, p. 61).

Neither has the diaspora played an autonomous role when it comes to the influx of foreign direct investment in Israel. Although the outgoing Israeli diaspora, especially that part of it located in the US, stands out for its famous generosity in terms of financial support and other forms of aid to Israel, it is not among the group of leading overseas investors.

Expatriate Israelis, however, have influenced a major boom in the Israeli tech industry. According to Zuckerman (2001, as cited in Diaspora Networks... 2006), the commercialisation of the defense industry stimulated growth in Israeli technology. The competences of the Israeli military in communications network security and management appeared to be integral to the development and support of the Internet. "Many technology pioneers were veterans of the elite intelligence services" (Diaspora Networks... 2006, p. 62). In turn, research and development work in this sector has been financed by the U.S. and Israeli government, while external funds have been procured thanks to effective lobbying by American Jews. Furthermore, the Jewish diaspora also helped attract venture capital, with some individuals acting as mentors and advisors to foreign investors.

Nevertheless, proper financing was not the only factor driving Israel's transition from a purely agricultural to an innovative high-tech economy. Namely, the success was largely attributable to human capital, which consisted not only of national engineers, but also of highly skilled Jews coming from abroad. Around 1 million Jewish immigrants from the former Soviet Union entered Israel in 1989 (de Fontenay \& Carmel 2002, p. 9). Many of them had engineering and scientific backgrounds, which helped them to succeed in the ICT industry. At the beginning of the 2000s, Israeli's high-tech cluster branched out to locations including Boston, Helsinki, London and Swedish Kista in order to harness the strength of cluster effects (de Fontenay \& Carmel 2002, p. 2).

\section{What about Ukraine?}

The diaspora has many faces, with some serving as human capital or direct investors, while others set a positive example for society or act as a diplomat. In any case, diaspora propels the home country's economic development. It is thus of crucial importance to consider those countries - Ukraine is certainly among them - which are in priority need of such assistance.

The most compelling reason for that is that Ukraine's economy is still adapting to new realities that have unfolded in the aftermath of Crimea's annexation, 
coupled with the 2014 armed conflict in Donbas, a key industrial area in eastern Ukraine.

After the country's loss of gas fields in the Black Sea shelf, tourism to Crimea and the metallurgical, mining, and chemical industries in Donbas, it has become apparent that Ukraine stands on the verge of great changes. Furthermore, the breakdown of commercial relations with Russia, a major export and import market for Ukraine, resulted in financial instability and the destruction of the traditional model used in the raw materials industry (Foresight of Ukrainian Economy 2017).

Under these circumstances, the experts have put forward a strategy that should be considered by decision-makers in the upcoming transition. Those experts maintain that modifying investment policy should be prioritised. The funds, supplied mostly via external loans, should not go towards financing low-tech or raw materials exports. In the light of increasing competition from China and India, such investments are unpromising. The growing supply of low technology products on the world markets leads to both lower prices and manufacturers' profits.

Ukraine would be well advised to establish itself in areas that enable it to leverage its international competitiveness. Gaining an optimal niche in the international division of labour will be possible thanks to the country's geographic situation and bountiful resources, both human and natural, which should trigger the development of its high-tech business (Foresight of Ukrainian Economy 2017).

Taking into account the example other countries have set, this study aims at examining the diaspora's role in Ukraine's economic development with a particular focus on the tech sector, the economy's main driving force.

In the context of other relevant work in the field, two studies should be noted. First, Migration as Enabler of Development in Ukraine (2016), prepared by the International Organization for Migration (IOM) Mission in Ukraine examined the nexus between development and migration-related financial flows. The other, the Ukrainian Diaspora Investment Study (2016) was produced for the United States Agency for International Development, and focused on the Ukrainian diaspora in the United States and Canada. Its authors asserted that "the Ukrainian diaspora in the United States and Canada is a highly organised, multi-generational, proud diaspora with significant human, financial, and social capital" (Ukrainian Diaspora Investment Study 2016). Given that diaspora identificational ties with Ukraine have strengthened on the heels of recents events in the country, remittances and travel to and volunteer work in the country have all grown. Nevertheless, impeded by the bad experience of previous diaspora as well as stories of corruption, few engage in business investment. When investments are made, they are targeted mainly at the ICT, agricultural, and educational sectors. Apart from the benefits which have traditionally motivated diaspora to invest - that is, financial, emotional, social status and political ones (Nielsen \& Riddle 2009) - 
the Ukrainian diaspora has prompted a fifth type of return: an expectation that the investment will bring about institutional change.

Undertaking a comprehensive study of migrant monetary flows to Ukraine, the authors of the Migration as Enabler of Development in Ukraine (2016) affirm that, "it is the determination of potential savings capacity, rather than absolute level of income, which commonly determines migration decisions and economic behaviours" (Migration... 2016). The savings rate of Ukrainian migration is the highest amongst the South-Eastern and Eastern Europe (SEEE) countries and amounts to $62 \%$ of household net income. To put this in figures, in 2014, USD 14,916 was saved out of the USD 24,156 of the average annual income earned by Ukrainian long-term migrant households.

The high propensity to save translates into the ability to remit and invest in the country of origin. Although the share of migrant households remitting to Ukraine is relatively high, the contribution of migration to GDP remains small, with remittances amounting to $2-5 \%$ of GDP (Migration... 2016). The general impact of migration and remittances to date has been to alleviate poverty and contribute to Ukraine's macro-economic stability. With most remittances funding consumption needs, the most important purposes of transferring money to Ukraine include supporting spouses, children and parents, as well as saving money.

Like the majority of migrant workers from SEEE countries, Ukrainian migrant workers do not perceive themselves as entrepreneurs. The remittances earmarked for investing in a business totalled $1 \%$ of the money Ukrainians transferred in 2014 (Migration... 2016).

The empirical data presented above, reflecting a lack of solid business engagement among Ukrainian migrants, justifies the intention to raise awareness among all stakeholders - policy makers, donors, the private sector and civil society - of the fact that labour migrants, diaspora, and transnational communities on the whole can play a crucial role in the developing their home country. In the case of Ukraine, the human, social and financial capital Ukrainians have can be used to develop the country.

\section{Methodology}

To examine diasporic activity in Ukraine's technology sector, an unstructured in-depth interview was conducted with a single key informant ${ }^{2}$.

According to Edwards and Holland (2013), the term "informant" has been widely used in ethnographic methods, where key characters within an investigated group, culture or community provide crucial information with regard to the research setting. The informant in my article was a Canadian of Ukrainian

2 The term "informant" is specifically applied instead of alternative interviewee, respondent, research subject or participant. 
descent, and a key figure playing a critical role in the development of Ukraine's high-tech sector. Not only is he the president of a globally competitive ICT, microelectronics and nanotechnology company, but he also manages an incubator that develops high-tech Ukrainian startups.

"Key informants have a formal or informal position that gives them specialist knowledge about the people and processes that are the subject of research" (Edwards \& Holland 2013, p. 31). The researcher, for his or her part, is considered an outsider who seeks to obtain relevant knowledge about the community.

Although one source of information may not be considered as credible and sufficient, there is no certain formula for choosing the relevant interview sample. In turn, the sample size is "completely dependent on the nature and design of the study, the aims and research questions and the underlying philosophical position adopted" (Edwards \& Holland 2013, p. 7).

In the case of today's investigation, the informant both belongs to the diaspora community and holds an executive position in Ukraine's tech sector. Belonging to the Ukrainian diaspora in Canada, and having the ability to interact with other members of the community on a daily basis enable the informant to provide particular insight. Furthermore, his executive role in Ukraine's tech sector gives him intimate knowledge of the developments taking place in the industry. All of these roles together make him a very legitimate choice for the key informant.

Intended to explore the informant's understanding of the subject and aspects of his experiences related to it, the interview was unstructured. Such an interview enables an informant to talk from his own point of view, referencing ideas and meanings that are familiar. The flexibility of an unstructured interview makes it possible "to develop unexpected themes and adjust the content of interviews and possibly the emphasis of the research as a result of issues that emerge in any interview" (Edwards \& Holland 2013, p. 30).

To elicit the informant's own story as it pertains to the research, a biographical approach has been employed. The questions containing the knowable portion of biographical data are intended to induce a non-interrupted narrative in the hope that it brings reveals new facts which are relevant for the investigation. Information obtained through the narrative can help to shed light on matters which the researcher could not otherwise understand or access.

The interview was conducted via email. This form of communication was selected due to geographical separation between the researcher and the informant. Apart from the logistical advantages, which obviously save time and resources, the technique also yieds a written document of the diasporan's experience. 


\section{The Results of the Analysis}

The first clear observation from the interview is that the Ukrainian diaspora in Canada is quite assimilated. When asked whether he considers himself Ukrainian or Canadian, the informant answered that he is Ukrainian-Canadian. He noted that "a great deal of Canadians are from immigrant backgrounds, so being hyphenated Canadian is quite normal".

However, assimilation with a host country does not always mean perceiving it as a homeland. I asked him if "you consider Canada as a host country, and Ukraine a homeland? Or vice versa?"

Unlike his parents, who migrated to Canada after the Second World War with no money or education, the informant had his personality and status totally shaped in the host country. He earned a university degree in Canada and started his career there. So it should come as no surprise that he considers Canada his home country. It may be concluded that second-generation diasporans are more bound to their adopted country than to their parents' country of origin.

This attachment, however, does not prevent diaspora from cultivating its original culture. In fact, participation in Ukrainian community organisations and learning the language were among the key factors compelling the informant to set up business in Ukraine. Specifically, when asked "What was the main driving force for you to develop business in Ukraine's tech sector?", the informant replied that being raised in the Ukrainian community and learning things about the country, he learned also that "Ukraine's legacy of R\&D and a base for technology for all of the USSR, there were a lot of smart people to work with". Other objectives influencing the informant's decision included a desire to take his career to another level and "develop a business from scratch in a whole new developing country".

The informant's former employer, Digital Equipment Corporation, the second largest IT company in the world, was able to develop thanks to the $\mathrm{COCOM}^{3}$ rules being terminated. Originally the company intended to open a branch in Moscow. However, the informant encouraged the company to consider Ukraine - a country as big as France - instead.

To assess the role of diaspora in Ukraine's transformation, I asked the informant, "if the Ukrainian diaspora in Canada strongly supports Ukraine's economic, social and political transformation; is this support tangible in tech sector?". The informant replied that Ukraine has always been and continues to be supported by the diaspora in Canada, which is broad and influential. According to the informant, Ukrainian diaspora in Canada has been engaged in a range of development projects over the past 25 years. The programmes have included

\footnotetext{
${ }^{3}$ Regulations which put embargo on export of high-tech to USSR during the Cold War.
} 
internships, military and law enforcement trainings, regional development programs, support for small and medium enterprises and universities.

When it comes to the developments in the tech sector, the informant himself is a bright example. He gave up a stable position in the host country in order to develop the company's activity in Ukraine, which resulted in job creation and the transfer of knowledge. And yet after establishing the business, he stayed in Ukraine in order to keep the sector growing through collaboration with universities and the creation of incubators for technology ventures.

According to the informant, apart from lobbying and financial assistance provided by the diaspora, Ukraine should also use the experience of countries like Canada, the US, Israel, Ireland, and Poland in developing its own tech industry. He adds that "Ukraine can learn from some of the best examples of economies that have recognised that technology will continue moving forward irrespective of what any one country does".

\section{Summary and Conclusions}

There are many definitions of the term "diaspora". This paper has reviewed the definitions that describe its essential features. To summarise, diaspora is always about a group of people living in a foreign country, not the individual immigrants. This is the main quality distinguishing diaspora from migration. Furthermore, diaspora can exist even if a nation-state no longer does. The experience of Tibetans, Kurds and Palestinians all attest to that. Other features that unify diaspora members include: a common sense of responsibility for, identification with and a desire to eventually return to a homeland.

Because diaspora cares about the well-being of the home country, it contributes in a variety of ways to its socio-economic development, including sending remittances, transferring knowledge and lobbying the home country's interests. India, China and Israel, among others, have benefitted economically from diaspora contributions.

Given the historical evidence for diaspora's prominent role in the development of particular countries, this study sought to examine if that roles also holds true for Ukraine, a country with one of the largest diasporas in the world. Accepting a reorientation to a high-tech business is the only way for Ukraine to guarantee development and progress. To do that, a great deal of the burden will be shouldered by the diaspora's contribution to this sector.

For this project, the best way to start exploring this subject was to directly communicate with the individual having intimate knowledge about the subject. Hence, interviews were conducted to shed light on issues we as researchers could 
not otherwise have understood or accessed. The interviews also made it possible to learn the motives of diasporic undertakings, which can be different from the objectives of non-Ukrainian entrepreneurs.

All in all, the analysis of the data collected indicates that there is a sincere need and desire for Ukraine to become successful. Even if not born and raised in Ukraine, diaspora members cultivate the culture and language, which helps them to get to know their country of origin. Consequently, when setting up a business or mentoring a project in Ukraine, they have way more privileges than non-Ukrainian entrepreneurs.

Furthermore, it was confirmed that Ukraine possesses important tools to develop its high-tech sector, including a technology base inherited from the USSR and skilled engineers. Whatever the reason an individual might be entering the Ukrainian market - from career growth to patriotic deed to gaining experience - it will be a win-win situation for both sides.

To sum up, this study has shown that the diaspora's role in the economic development of Ukraine is present in many dimensions, including the tech sector. The expertise and incentive diaspora can bring to its home country benefits both the individual and the country. Nevertheless, Ukraine's diaspora community has failed to harness its full potential in terms of investing social, financial or human capital to their home country. That makes it important to convince both the transnational community, including labour migrants and diaspora, and Ukraine's policy makers and civil society that their role in the country's development matters.

This study constitutes a first step in that direction. However, it comes with limitations. First and foremost, the article evaluates a tiny aspect of possible diaspora contribution to Ukraine's development, but does not measure its factual impact on that development. Second, the state of affairs has been guaged primarily by in-depth interview, and that from the perspective of Ukrainians living in Canada, the largest Ukrainian diaspora host country. Because these limitations result from insufficienct data, future studies will seek to bridge the research gap by collecting more raw data. This will be accomplished by creating focus groups and in-depth interviews with Ukrainian's in more than one country beyond their homeland.

\section{Bibliography}

Agunias D. R., Newland K. (2012), Developing a Road Map for Engaging Diasporas in Development, IOM, Geneva, https://publications.iom.int/system/files/pdf/diaspora_ handbook_en_for_web_28may2013.pdf (accessed: 21.12.2017).

Anthias F. (2007), Ethnic Ties: Social Capital and the Question of Mobilisability, "The Sociological Review", vol. 55, no. 4, https://doi.org/10.1111/j.1467-954x. 2007.00752.x. 
Bowles S., Gintis H. (2004), Persistent Parochialism: Trust and Exclusion in Ethnic Networks, "Journal of Economic Behavior \& Organization", vol. 55, no. 1, https://doi. org/10.1016/j.jebo.2003.06.005, https://doi.org/10.1016/j.jebo.2003.06.005.

Clifford J. (1994), Further Inflections: Toward Ethnographies of the Future, "Cultural Anthropology", vol. 1, no. 3, http://wayneandwax.com/pdfs/clifford_diasporas.pdf (accessed: 21.12.2017).

Constant A. F., Zimmermann K. F. (2016), Diaspora Economics: New Perspectives, "International Journal of Manpower", vol. 37, no. 7, https://doi.org/10.1108/ IJM-07-2016-0151.

Damm A. P. (2009), Ethnic Enclaves and Immigrant Labor Market Outcomes: Quasi-experimental Evidence, "Journal of Labor Economics", vol. 27, no. 2, https://doi. org/10.1086/599336.

Dhanani Q., Lee M. (2013), Diaspora Investing - The Business and Investment Interests of the Caribbean Diaspora, World Bank, Washington, DC, https://openknowledge. worldbank.org/handle/10986/17610 (accessed: 21.12.2017).

Diaspora Networks and the International Migration of Skills: How Countries Can Draw on Their Talent Abroad (2006), Y. Kuznetsov (ed.), World Bank Institute, World Bank, Washington, DC, https://openknowledge.worldbank.org/handle/10986/7008 (accessed: 21.12.2017).

Dutia S. G. (2012), Diaspora Networks. A New Impetus to Drive Entrepreneurship, "Innovations. Technology, Governance, Globalization", vol. 7, no. 1, https://doi.org/10.1162/ inov_a_00116.

Edwards R., Holland J. (2013), What Is Qualitative Interviewing? (in:) G. Crow (ed.), "What Is?" Research Methods Series, University of Edinburgh, http://eprints.ncrm. ac.uk/3276/1/complete_proofs.pdf (accessed: 21.12.2017).

Elo M. (2014), Diaspora Networks in International Business and Transnational Entrepreueurship - A Literature Review, "Zentra Working Paper Series in Transnational Studies", no. 40.

Fontenay C. de, Carmel E. (2002), Israel's Silicon Wadi: The Forces behind Cluster Formation (in:) T. Bresnahan, A. Gambardella, A. Saxenian (eds), Silicon Valley and Its Imitators, http://www.ebusinessforum.gr/old/content/downloads/Israel.pdf (accessed: 21.12.2017).

Foresight of the Ukrainian Economy: Mid-term (2015-2020) and Long-term (2020-2030) Time Horizons (2017), International Council for Science (ICSU), Committee for the System Analysis of the Presidium of the NAS of Ukraine, National Technical University of Ukraine "Kyiv Polytechnic Institute", Institute for Applied System Analysis of the NAS of Ukraine and MES of Ukraine, World Data Center for Geoinformatics and Sustainable Development, 2nd ed., NTUU “KPI”, Publishing House, Kyiv, http://wdc. org.ua/en/node/182604 (accessed: 21.12.2017).

Harima A. (2014), Network Dynamics of Descending Diaspora Entrepreneurship: Multiple Case Studies with Japanese Entrepreneurs in Emerging Economies, "Journal of Entrepreneurship, Management and Innovation", vol. 10, no. 1, https://doi. org/10.7341/20141043.

Harima A., Vemuri S. (2015), Diaspora Business Model Innovation, "Journal of Entrepreneurship Management and Innovation", vol. 11, no. 1, https://doi.org/10.7341/20151113.

Homans G. (1961), Social Behavior: Its Elementary Forms, Harcourt Brace, New York. 
Kloosterman R., Leun J. van der, Rath J. (1999), Mixed Embeddedness. (In)formal Economic Activities and Immigrant Business in the Netherlands, "International Journal of Urban and Regional Research", vol. 23, no. 2, https://doi.org/10.1111/1468-2427.00194.

Lazarsfeld P. F., Merton R. K. (1954), Friendship as a Social Process (in:) M. Berger et al. (eds), Freedom and Control in Modern Society, Van Nostrand, Princeton.

Meyer J. B., Wattiaux J. P. (2006), Diaspora Knowledge Networks: Vanishing Doubts and Increasing Evidence, "International Journal on Multicultural Societies", vol. 8, no. 1.

Migration as an Enabler of Development in Ukraine. A Study on the Nexus between Development and Migration - Related Flows to Ukraine (2016), International Organization for Migration, Kyiv, http://www.iom.org.ua/sites/default/files/iom_migration_as_an_enabler_of_development_in_ukraine.pdf (accessed: 18.10.2018).

Nielsen T. M., Riddle L. (2009), Investing in Peace: The Motivational Dynamics of Diaspora Investment in Post-conflict Economies, "The Journal of Business Ethics", vol. 89, no. 4, https://doi.org/10.1007/s10551-010-0399-z.

Nikolova M., Roman M., Zimmermann K. F. (2016), Left behind but Doing Good? Civic Engagement in Two Post-socialist Countries, "Journal of Comparative Economics", https://doi.org/10.1016/j.jce.2016.04.006.

Safran W. (1991), Diasporas in Modern Societies: Myths of Homeland and Return, “Diaspora: A Journal of Transnational Studies", vol. 1, no. 1, https://doi.org/10.1353/ dsp.1991.0004.

Thibaut J., Kelly H. (1959), The Social Psychology of Groups, Wiley, New York.

Tölölyan K. (1991), The Nation State and Its Others: In Lieu of a Preface, "Diaspora: A Journal of Transnational Studies", vol. 1, no. 1, https://doi.org/10.1353/dsp.1991.0008.

Ukrainian Diaspora Investment Study (2016), The United States Agency for International Development (USAID), Washington, DC, https://pdf.usaid.gov/pdf_docs/PA00M5ZW. pdf (accessed: 18.10.2017).

\section{Rola diaspory w transformacji gospodarki Ukrainy z surowcowej w przemysłową}

(Streszczenie)

Celem artykułu jest określenie roli diaspory w rozwoju przemysłu technologicznego na Ukrainie. Dokonany przegląd literatury pozwolił na lepsze zrozumienie terminu „diaspora” oraz wskazanie różnic pomiędzy tym pojęciem a pojęciem migracji. Podano przykłady państw, w których rozwoju gospodarczym diaspora odegrała kluczową rolę, co potwierdziło zasadność analizy tego zjawiska na Ukrainie.

W celu opisania działań diaspory w sektorze technologicznym na Ukrainie oraz określenia ich motywów przeprowadzone zostały badania empiryczne w formie pogłębionego wywiadu z kluczowym informatorem. Wyniki badań wskazują na to, że wkład diaspory jest obecny w wielu dziedzinach rozwoju gospodarczego Ukrainy, w tym w sektorze technologicznym. Motyw podejmowania przedsięwzięć, który odróżnia diasporę od przedsiębiorców spoza Ukrainy, to poczucie odpowiedzialności za dobrobyt swojego kraju pochodzenia.

Słowa kluczowe: diaspora, migracja, Ukraina, technologia, rozwój gospodarczy. 